О.В. Філіппенков ${ }^{1}$, В.І. Самоквіт ${ }^{1}$, М.М. Адамчук ${ }^{2}$, Г.М. Дементіюк ${ }^{1}$

${ }^{1}$ Харківський національний університет Повітряних Сил ім. І. Кожедуба, Харків

${ }^{2}$ Наџіональна академія Наџіональної гвардї України, Харків

\title{
АНАЛІЗ ОСОБЛИВОСТЕЙ ОПЕРАТИВНОГО ПЛАНУВАННЯ ПРОТИПОВІТРЯНОЇ ОБОРОНИ СУХОПУТНИХ ВІЙСЬК ОБ'ЄДНАНИХ СИЛ ЗА СТАНДАРТАМИ НАТО
}

\begin{abstract}
Проведено аналіз особливостей організаиії та здійснення оперативного планування протиповітряної оборони (ППО) сухопутних військ (СВ) об'єднаних сил за стандартами НАТО. На прикладі угруповання об'єднаних сил (ОС) США наведений розподіл обов'язків щодо планування ППО між командуванням ОС та його функиіональними складовими. Визначені основні складові ППО СВ в складі угруповання ОС США. Показано, що Командування ППО СВ несе загальну відповідальність за планування операцій з ППО та протиракетної оборони (ПРО) сухопутної компоненти ОС, координацію і синхронізацію планування на рівні армійського корпусу та дивізії. Проведено аналіз організаиії планування ППО/ПРО на рівні армійського корпусу СВ та бригади ППО СВ на театрі воєнних дій (ТВД). Показано, що можливості бригади ППО на ТВД дозволяють організувати планування на рівнях командування ППО СВ та армійського корпусу. Складено узагальнену схему прочесів планування ППО/ПРО сухопутної складової ОС на ланках управління від Командування ОС до батарей ППО СВ. Визначено, що ключовими документами з планування ППО є список важливих об'єктів та список прикриття, розроблення яких є динамічним та інтерактивним процесом відповідно до етапу (фази) операиії. Визначені взаємопов 'язані етапи розроблення списку об' єктів прикриття та надано характеристику методів які для цього використовуються.
\end{abstract}

Ключові слова: протиповітряна оборона, оперативне планування, операиія Об'єднаних сил, список важливих об' єктів, список об'єктів прикриття, СVT-аналіз.

\section{Вступ}

Постановка проблеми. Для забезпечення взаємосумісності застосування підрозділів та частин Сухопутних військ (CB) Збройних Сил (3С) України та країн НАТО постає актуальним питання впровадження стандартів підготовки та прийняття рішень країн-партнерів у вітчизняну практику військ.

Аналіз останніх досліджень і публікацій. Аналіз існуючих стандартів оперативного планування протиповітряної оборони (ППО) СВ передових країн НАТО вказує, що в їх основі лежить методологія прийняття військових рішень в рамках процесу MDMP - Military Decision-Making Process, який складається 37 стандартизованих етапів - кроків [1-2]. Цей процес інтегрує діяльність командира, штабу, підпорядкованих, приданих і взаємодіючих штабів $з$ метою розуміння обстановки та бойового завдання, розробки і порівняння варіантів бойових дій (COA - Course of Action), вибору варіанту бойових дій, а також розробки операційного плану (OPLAN - Operations Plan) та (або) операційного наказу (OPORD - Operation Order) [1-2].

Підходи для реалізації етапів $M D M P$ під час планування протиповітряної оборони мають важливі відміни у порівнянні із аналогічними етапами для механізованих військ, які добре проаналізовані у вітчизняній літературі [3-5]. Це ускладнює використання процедур $M D M P$ для оперативного планування ППО Сухопутних військ особливо для умов угруповання Об'єднаних Сил, які вимагають високу ступінь координації між складовими компонентами.

Аналіз існуючої літератури вказав на практичну відсутність вітчизняних робіт в яких питання аналізу організації та здійснення оперативного планування протиповітряної оборони сухопутної складової операцій Об'єднаних сил за стандартами НАТО. Серед відомих робіт можна визначити [6].

Задля заповнення вказаного пробілу, аналізу передового світового досвіду для його впровадження в існуючі та перспективні стандарти оперативного планування ППО Сухопутних військ метою статті $\epsilon$ аналіз організації планування протиповітряної оборони сухопутної компоненти на прикладі угруповання Об'єднаних сил США (JF - Joint Forces).

\section{Виклад основного матеріалу}

\section{1. Планування протиповітряної оборони операції на рівні Командування Об'єднаних сил та його функціональних складових}

Як правило до складу угруповання ОС США входять наступні функціональні складові, кожна 3 
яких має відповідні командування та власні сили i засоби ППО (ПРО) [7-8]:

1) повітряні сили (AFFOR - Air Force Forces);

2) сухопутні сили (ARFOR - Army Forces);

3) морські сили (NAVFOR - Navy Forces);

4) сили корпусу морської піхоти (MARFOR Marine Corps forces);

5) угруповання Сил спеціальних операцій (JSOTF - Joint Special Operations Task Force).

Командувач об'єднаних сил (ОС) відповідає за управління, визначення пріоритетів, завдань та концепції операцій для підлеглих командирів (командувачів) які діють у спільній операційній зоні [5] в тому числі для операцій з ППО/ПРО. В ході стандартизованого процесу прийняття військових рішень в країнах НАТО [1-2] командування ОС (Joint Force Command) розробляє загальний операційний план $O P L A N$ в якому серед іншого визначаються наступні важливі для організації ППО/ПРО складові [9-10]:

1) завдання операції ОC (Mission);

2) поточна обстановка (Situation), що грунтується на результатах проведеної розвідувальної підготовки поля бою (IPB - Intelligence Preparation of the Battlefield), яка враховує повітряного противника та ракетні загрози;

3) пріоритети та концепція операцій (CONOPS - Concept of Operations) 3 ППО/ПРО;

4) часткові завдання, які мають бути обов'язково виконані для успішного виконання операцій з ППО/ПРО.

За OPLAN слідує видання операційного наказу (OPORD - Operational Order), що надсилається підлеглим командуванням функціональних складових та армійським корпусам. OPORD серед іншого визначає [9]:

1) список важливих об'єктів (сил) (CAL - Critical Assets List) які мають бути прикритими та вказуються необхідні рівні захисту від ударів з повітря. $C A L$ стає основою для подальшого розроблення списку об'єктів прикриття (DAL - Defended Assets List) в якому визначено пріоритети захисту від ударів 3 повітря об'єктів (сил) відповідно до етапу (фази) операції. Він розробляється відділом $J 3 / 5$ штабу OC. Вхідні дані для формування $C A L$ надходять від складових компонентів угруповання ОС, які визначають кандидатів серед об'єктів (сил), які необхідно захистити від ударів 3 повітря. Командувач ОС затверджує список важливих об'єктів (сил) котрий потім включається до операційних планів, які розробляються на рівні функціональних складових ОС.

2) порядок взаємного прикриття між силами ППО/ПРО безпосередньо підпорядкованих командувачу ОС та частинами (підрозділами) з ППО/ПРО зі складу функціональних складових ОС;

3) порядок управління операції з ППО/ПРО в т.ч. правила застосування зброї (ROE - Rules of
Engagement) для типових повітряних загроз;

4) порядок забезпечення операції з ППО/ПРО.

Список важливих об'єктів прикриття $C A L-\epsilon$ списком об'єктів (сил), пріоритет яких визначено у відповідності до фази операції ОС.

Як правило, командувач ОС доручає командувачу повітряних сил - JFACC (Joint Forces Air Component Commander) та командуванню ППО/ПРО СВ (AAMDC - Army Air and Missile Defense Command) розробити список об'єктів прикриття $D A L$ із залученням вихідних даних від усіх складових компонентів ОС. Разом із $D A L$ визначаються необхідні рівні показників ефективності ураження цілей (перехоплення ракет) необхідних для збереження визначених об'єктів (сил).

Таблиця 1

Складові ППО/ПРО СВ складі ОС США

\begin{tabular}{|c|c|c|c|}
\hline № & $\begin{array}{c}\text { Частина } \\
\text { (підрозділ) } \\
A D A \\
\end{array}$ & Призначення & Основні засоби \\
\hline 1 & 2 & 3 & 4 \\
\hline 1. & $\begin{array}{l}\text { Команду- } \\
\text { вання ППО } \\
\text { СВ } \\
(A A M D C)\end{array}$ & $\begin{array}{l}\text { орган управління } \\
\text { ARFOR для плану- } \\
\text { вання, управління, } \\
\text { координація та інте- } \\
\text { грація сил і засобів } \\
\text { ППО фунціональ- } \\
\text { них складових ОС на } \\
\text { рівні театру воєнних } \\
\text { дій (ТВД) }\end{array}$ & $\begin{array}{l}\text { автоматизована } \\
\text { система (АСУ) } \\
\text { управління та пла- } \\
\text { нування ППО/ПРО } \\
\text {-AMDPCS- - Air } \\
\text { and Missile Defense } \\
\text { Planning and } \\
\text { Control System. }\end{array}$ \\
\hline 2. & \begin{tabular}{|l} 
Бригада \\
ППО СВ на \\
ТВД (ADA- \\
Brigade \\
Theatre)
\end{tabular} & $\begin{array}{l}\text { засіб ARFOR для } \\
\text { прикриття визначе- } \\
\text { них сил на рівні опе- } \\
\text { ративних угруповань } \\
\text { військ (ОУВ), армій- } \\
\text { ських корпусів (АК) } \\
\text { та стратегічних } \\
\text { об'єктів ТВД від } \\
\text { повітряного против- } \\
\text { ника та атмосферно- } \\
\text { го перехоплення } \\
\text { балістичних та кри- } \\
\text { латих ракет }\end{array}$ & $\begin{array}{l}\text { ACУ AMDPCS та } \\
\text { ACУ Patriot TCS - } \\
\text { Tactical Command } \\
\text { System, зенітно- } \\
\text { ракетний комплекс } \\
\text { (ЗРК) Patriot. }\end{array}$ \\
\hline 3. & $\begin{array}{l}\text { Батареї } \\
\text { тактичної } \\
\text { ПРО } \\
(\text { THAAD } \\
\text { battery) } \\
\end{array}$ & $\begin{array}{l}\text { засіб ARFOR (ОУВ / } \\
\text { АК СВ) для (поза) } \\
\text { атмосферного пере- } \\
\text { хоплення балістич- } \\
\text { них ракет }\end{array}$ & $\begin{array}{ll}\text { система } & \text { ПРО } \\
\text { THAAD. } & \end{array}$ \\
\hline 4. & $\begin{array}{l}\text { Батальйони } \\
\text { ППО СВ } \\
(\text { ADA battal- } \\
\text { ion })\end{array}$ & $\begin{array}{l}\text { засіб ППО АК (диві- } \\
\text { зії СВ) для прикрит- } \\
\text { тя визначених сил та } \\
\text { об'єктів від повітря- } \\
\text { ного противника }\end{array}$ & $\begin{array}{l}\text { АCУ Patriot TCS та } \\
\text { (або) АCУ FAAD } \\
\text { C3I; РЛС Sentinel; } \\
\text { 3РК Patriot та (або) } \\
\text { 3РК Avenger. }\end{array}$ \\
\hline 5. & \begin{tabular}{|l} 
Батареї \\
(вогневі \\
групи - FU \\
- Fire Units) \\
ППО СВ \\
малої даль- \\
ності \\
(SHORAD - \\
Short Range \\
Air Defense \\
battery)
\end{tabular} & $\begin{array}{l}\text { засіб ППО бригади } \\
\text { (батальйону) СВ для } \\
\text { прикриття визначе- } \\
\text { них сил в рухомих } \\
\text { формах бою від по- } \\
\text { вітряного противни- } \\
\text { ка та об'єктів }\end{array}$ & $\begin{array}{l}\text { 3РК: Avenger; Line- } \\
\text { backer, переносний } \\
\text { ЗРК Stinger; бойова } \\
\text { машина BSFV. }\end{array}$ \\
\hline
\end{tabular}


Закінчення табл. 1

\begin{tabular}{|c|c|c|c|}
\hline 1 & 2 & 3 & 4 \\
\hline 6. & 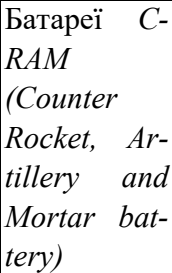 & $\begin{array}{l}\text { засіб захисту від } \\
\text { поодиноких ракет- } \\
\text { них, артилерійських } \\
\text { та мінометних об- } \\
\text { стрілів базових та- } \\
\text { борів підрозділів та } \\
\text { частин СВ. }\end{array}$ & $\begin{array}{l}\text { АСУ FAAD C3I; } \\
\text { РЛС } \quad \text { Sentinel та } \\
\text { AN/TPQ-36; зеніт- } \\
\text { на артилерійський } \\
\text { комплекс Phalanx. }\end{array}$ \\
\hline
\end{tabular}

Джерело: розроблено авторами.

Обов'язки JFACC можуть включати, але не обмежуються наступними функціями, пов'язаними із плануванням ППО/ПРО: ПРО;

1) планування повітряних операцій 3 ППО /

2) координація повітряних операцій з наземними операціями з ППО / ПРО;

3) розподіл завдань спільної операції по зв'язкам із громадськістю, тощо.

Разом з тим $J F A C C$ розробляє наступні вихідні документи для подальшого планування ППО / ПРО в межах $\mathrm{OC}$ :

1) наказ на виконання завдань в повітрі (АTO Air Tasking Order), який містить інструкції щодо наряду сил і спроможностей авіації, розподілу польотів по конкретним завданням та цілям.

2) наказ з управління повітряним простором (ACO - Airspace Control Order) - який є частиною $A T O$ та відображає план управління повітряним простором та заходи контролю за повітряним простором (Airspace Control Measures).

Роль командування $A A D C$ полягає в синхронізації наземних протиповітряних та протиракетних операцій.

Таким чином командування $J F A C C$ та $A A D C$ мають забезпечити централізоване керівництво, координацію та інтеграцію спроможностей щодо операцій в повітрі. Результатом сумісної роботи штабів $J F A C C$ та $A A D C$ є план ППО/ПРО першого порядку (Rough First - Order Air Defense Plan) в якому зусилля $з$ ППО розподіляються між функціональними компонентами ОС.

Військам ППО Сухопутних військ США ( $A D A$ - Air Defence Artillery) відводиться ключова роль в забезпеченні ППО та ПРО сухопутної компоненти ОС [8-9]. Тому далі зупинимося на особливостях організації та здійснення планування $A D A$.

Типові сили ППО/ПРО СВ США в складі ОС [9-11] наведено в табл. 1.

\section{2. Зміст планування на рівні} командування ППО/ПРО СВ США (AAMDC)

Командування ППО/ПРО СВ США $A A M D C$ несе загальну відповідальність за планування операцій з ППО та ПРО для підтримки сухопутної компоненти ОC - ARFOR.

Для цього командування $A A M D C$ :
- уточнює список важливих об'єктів $C A L$ отриманий від командування $\mathrm{OC}$;

- виробляє, або приймає участь у виробленні разом із $J F A C C$, списку об'єктів прикриття $D A L$ для його подальшого затвердження командувачем OC;

- визначає склад сил і засобів $A D A$ та їх завдання в ході операції ОС в залежності від необхідних спроможностей системи прикриття від ударів 3 повітря.

Особовий склад $A A M D C$ здійснює заходи з планування у наступному порядку [9]:

1) аналіз та уточнення визначеного завдання;

2) аналіз та уточнення АТО та АСО;

3) аналіз та уточнення списку критично важливих об'єктів (сил), які потребують прикриття;

4) оцінювання складу, стану та положення противника - в ході IPB;

5) оцінювання складу, стану та варіантів розподілу наявних сил і засобів ADA для захисту критично важливих об'єктів (сил) від можливих загроз;

6) визначення спроможності щодо забезпечення потрібного рівня захисту важливих об'єктів (сил) наявними силами і засобами ADA;

7) формування вимог на додаткові сили і засоби ППО/ПРО до функціональних складових ОС при неможливості досягнення потрібного рівня захисту від ударів 3 повітря. Повідомлення командувача ОС про ступінь ризику від ударів з повітря для підлеглих об'єктів (сил) при неможливості виділення необхідних сил та засобів.

Основними результатами планування $A A M D C \epsilon$ :

- OPLAN та OPORD з ППО / ПРО для операційної зони $A R F O R$;

- створення оверлею до OPLAN та OPORD 3 ППО / ПРО для операційної зони ARFOR;

Виходячи 3 викладеного порядку та типових складових ППО/ПРО СВ (табл. 1) основне завдання командування $A A M D C$ полягає в визначенні складу та бойових завдань підпорядкованій бригаді ППО на ТВД та (або) батареям тактичної ПРО. У випадку, коли командування $A A M D C$ на ТВД не розгортається, відповідальність за планування, як правило, покладається на бригаду ППО СВ зі складу ОС [9-10]. Для забезпечення загальних зусиль ППО/ПРО Сухопутних військ в межах ТВД командування $A A M D C$ повинно координувати та синхронізувати планування протиповітряної та протиракетної оборони на рівні армійського корпусу та дивізіі.

\section{3. Зміст планування ППО/ПРО на рівні армійського корпусу СВ зі складу ОС}

На рівні АК виконують, по суті аналогічні функції планування та формують аналогічні документи планування, що і на рівні $A A M D C$. Головна відміна полягає у приділенні основної уваги прикриттю маневрених сил та важливих об'єктів (сил) у смузі дій корпусу. Оскільки АК не має відповідних сил і засо- 
бів автоматизованого планування ППО/ПРО типу $A M D P C S$, він може використовувати можливості бригади ППО для виконання більшості завдань 3 планування [9-10].

Результатами планування АК є розроблення додатку з ППО/ПРО до корпусного операційного плану. В ході процесу планування корпус визначає завдання підлеглих силам і засобам ППО зі свого складу та здійснює координацію з бригадою ППО яка підтримує його дії та групами взаємодії визначеними для підтримки. Наявність сил і засобів ППО/ПРО корпусу та визначення відповідних бойових завдань підлеглим базуються на пріоритетних завданнях та загальній схемі маневру армійського корпусу (Scheme of Maneuver).

Для забезпечення зосередження та синхронізації зусиль корпусу з зусиллями сил і засобів ППО/ПРО на ТВД командуванням $A A M D C$ здійснює координацію планування ППО/ПРО корпусу та бригади ППО СВ на рівні ТВД.

\section{4. Зміст планування ППО/ПРО на рівні бригади ППО СВ на ТВД зі складу ОС}

Командир бригади та його штаб ознайомлюються з OPORD від вищого штабу та аналізує: поставлене завдання, обстановку, концепцію операцій, часткові завдання та пріоритети ППО та іншу інформацію.

Після цього розробляється власний операційний план $O P L A N$, в якому уточняється порядок виконання тактичних операцій (протиповітряних боїв) в операційній зоні бригади [9-11].

OPLAN (OPORD) бригади ППО включає в себе:

- уточнене завдання та часткові бойові завдання;

- об'єкти (сили) що прикриваються;

- склад вогневих груп, необхідних для прикриття;

- заходи управління та координації.

В якості додатків та доповнень до OPLAN $(O P O R D)$ бригади ППО розробляються:

- списки $C A L$ та $D A L$;

- рішення щодо ризиків (Risk Decisions) і заходи щодо їх зменшення (Risk Mitigation Measures);

- додаток щодо ведення операцій (Operations Annex);

- порядок відкриття та ведення вогню (Fires Appendix) та інші допоміжні таблиці та форми.

Кількість вогневих груп, що створюються бригадою, визначається шляхом використання списку важливих об'єктів $D A L$ та рівнів показників ефективності прикриття (ефективності перехоплення цілей), які встановлені командувачем ОС. Критично важливі об'єкти (сили) розміщуються в базі даних (наносяться на оверлеї) та передаються підлеглим батальйонам ППО разом із операційним наказом.

Зміни в списку $D A L$ відповідно до етапу (фази) операції (бою) або зміна пріоритету особливо важливих об'єктів, як правило, впливає на пріоритети у забезпеченні та потребують постійної оцінки відповідним персоналом.

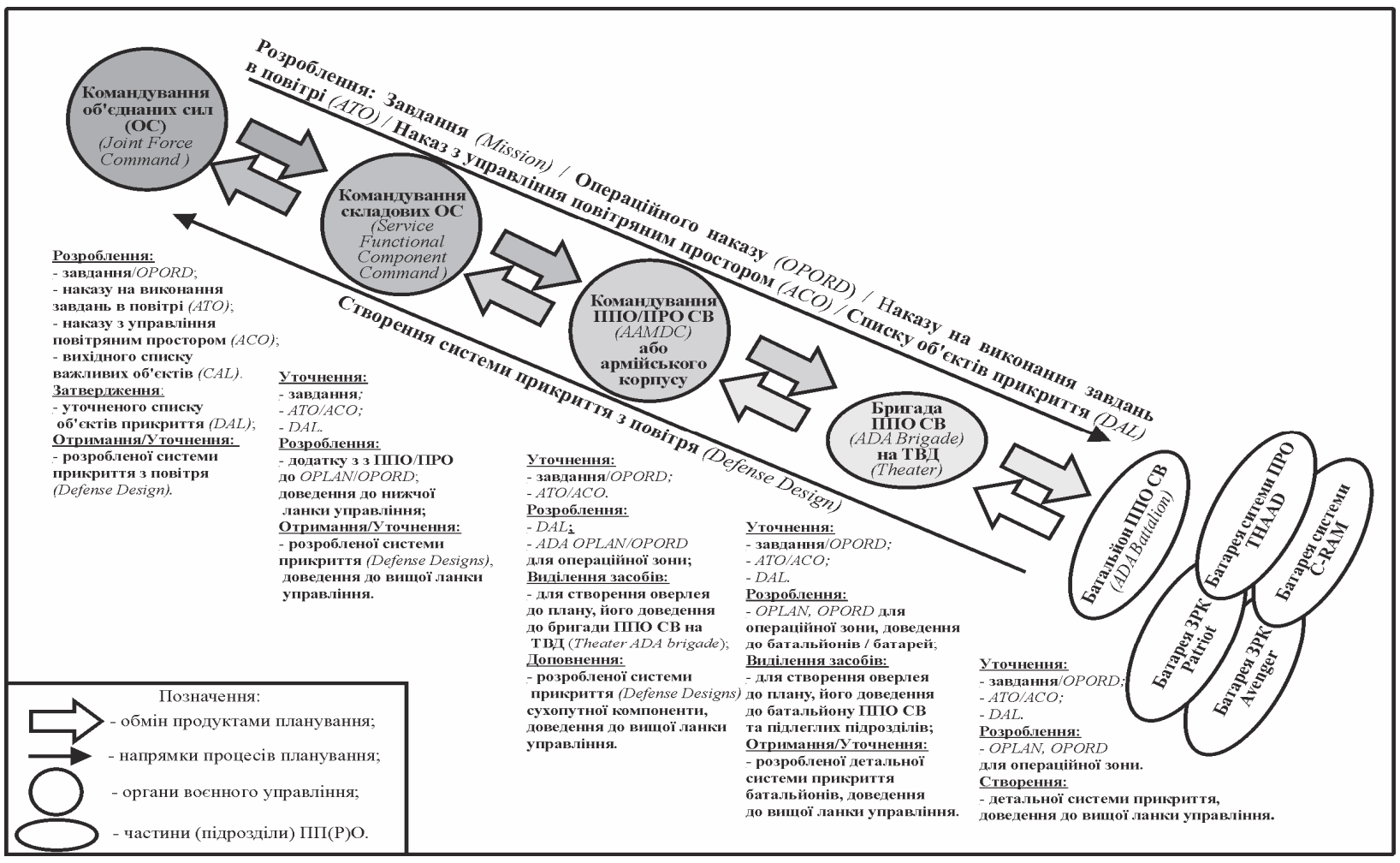

Рис. 1. Узагальнена схема процесів планування ППО/ПРО угруповання об'єднаних сил США Джерело: розроблено авторами. 
2. Загальні особливості процесу планування ППО/ПРО ОС за стандартами НАTO

За результатами аналізу процесів планування розглянутих складових можна визначити, що до планування ППО/ПРО залучаються всі компоненти OC, в тому числі Командування ОС та функціональних складових ОС; Командування ППО/ПРО СВ та армійських корпусів, бригади ППО СВ, батальйони та батареї ППО, ПРО та $C-R A M$.

На кожному з рівнів управління процес планування розпочинається 3 отримання завдання 3 вищого штабу та закінчується виробленням плану операції OPLAN або операційного наказу OPORD. Вони визначають напрямок планування для підлеглих яке здійснюється за процедурами $M D M P$. Планування здійснюється одночасно на всіх ланках управління паралельним методом із взаємним обміном результатами.

На рис. 1 складено узагальнену схему процесів планування ППО/ПРО сухопутної складової ОС на різних ланках управління. Як виходить 3 аналізу рис. 1 список об'єктів прикриття $D A L$ є одним 3 ключових документів планування протиповітряної та протиракетної оборони сухопутної складової ОС. Його розроблення є динамічним та інтерактивним процесом в якому приймають участь всі органи управління $A D A$ у відповідності до етапу (фази) операції.
Після перегляду початкового списку $D A L$ який надходить від вищого штабу, підлеглі командири та їх штаби можуть визначати додаткові об'єкти (сили) та пропонувати їх включення до $D A L$. При цьому командувач ОС та його штаб можуть включити одну або декілька пропозицій підлеглих та видати оновлений $D A L$ (зі зміненими пріоритетами). Така система планування дозволяє максимально реалізувати переваги ключового принципу організації ППО країн НАТО “Централізоване управління - децентралізоване виконання” [12-13].

В основу процесу розроблення списку важливих об'єктів покладено оцінювання важливих об'єктів (сил) визначених в CAL.

Через обмеженість наявних ресурсів сил і засобів для прикриття від ударів 3 повітря в задачі розроблення $D A L$ входить виконання наступних взаємопов'язаних етапів:

1) експертне оцінювання важливих об'єктів (сил) за критеріями, що дозволяють обгрунтовано визначити їх пріоритети [14];

2) оцінювання можливостей сил і засобів ППО та ПРО та можливих варіантів побудови системи прикриття важливих об'єктів (сил) від ударів 3 повітря. Обрати варіанти побудови системи прикриття від ударів з повітря (Defense Design), що забезпечують визначений рівень прикриття важливих об'єктів у відповідності до визначених пріоритетів та етапу (фази) операції [9];

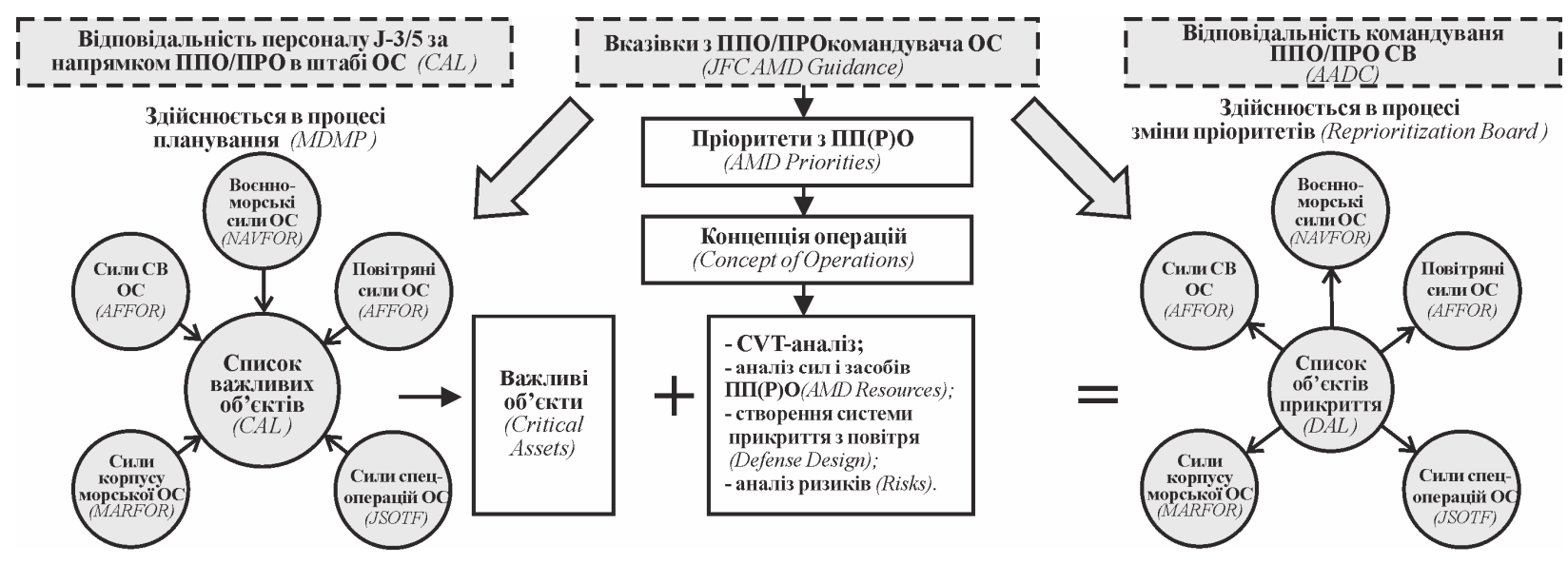

Рис. 2. Узагальнена схема розроблення списків $C A L$ та $D A L$ Джерело: розроблено авторами.

3) оцінювання ризиків для обраного варіанту побудови системи прикриття від ударів з повітря та вироблення пропозиції в рішення відповідних командувачів (командирів) щодо ризиків важливим об’єктам (силам) (Risk Decisions) та розробити заходи по їх зменшенню (Risk Mitigation Measures) [15].

В якості прикладу на рис. 2 наведено узагальнену схему розроблення списків $C A L$ та $D A L$.

Як видно з рис. 2 на першому етапі розроблення $D A L$ використовується метод $C V T$-аналізу за на- ступними критеріями: “Критичність” (Criticality), “Чутливість" (Susceptibility), “Відновлюваність" (Recuperability) [9; 14]. Детально зупинимося на сутності методу $C V T$-аналізу як основі для створення системи прикриття від ударів з повітря. Критерій "Критичність" (Criticality) - визначає міру важливості об’єктів (сил) для виконання поставленого завдання, що оцінюється по впливу на операцію імовірної шкоди (нанесення збитків) відповідним об'єктам (силам) за рівнями: 
- повністю виключає план операції;

- суттєво заважає реалізації плану;

- здійснює обмежений вплив на план.

Комплексний критерій “Уразливість” (Vulnerability) - складається 3 критеріїв:

- “Чутливість" (Susceptibility) міра стійкості до ураження повітряного противника та розосередження в просторі (здатності до маневру);

- "Відновлюваність" (Recuperability) - це ступінь можливості відновитися від завданих збитків (заподіяної шкоди) відповідним об'єктам (силам) 3 точки зору наявних та необхідних ресурсів для продовження власного функціонування.

Критерій “Загроза” (Threat) - це оцінка ймовірністі того, що відповідний об’єкт (сили) будуть ціллю спостереження або повітряного (ракетного) нападу з боку противника. Оцінювання грунтується на результатах розвідувальної підготовки поля бою IPB [16]. В якості прикладу наведено робочу таблицю (табл. 2) CVT-аналізу на прикладі типових об’єктів бригадної тактичної групи (бртгр) зі складу ОС. Як видно в табл. 2 об’єкти (сили) розміщені у порядку убування пріоритету після оцінювання за визначеними критеріями. 3 табл. 2 виходить, що $C V T$-аналіз передбачає кількісне оцінювання за вказаними критеріями яке здійснюється шляхом обробки експертних оцінок методами ранжування та шкальних оцінок [17]. До недоліків методу можна віднести [17] потенційну неузгодженість (слабку конкордацію) оцінок експертів, що в першу чергу пов'язано зі складністю ранжування важливості об'єктів в умовах їх великої кількості та застосуванням незважених шкальних оцінок.

\section{Висновки}

1. Проведено аналіз організації планування протиповітряної оборони операції на рівні Командування Об'єднаних сил за стандартами НАТО. На прикладі угруповання Об'єднаних сил США наведено розподіл обов'язків щодо планування ППО між Командуванням ОС та його функціональними складовими. Зокрема показано, що основну роль у плануванні відіграють Командування повітряної складової ОС (JFACC) та Командування ППО/ПРО СВ $(A A M D C)$. Розподіл обов'язків між ними з плану- вання ППО/ПРО здійснює Командувач ОС.

2. Визначені основні складові ППО/ПРО СВ складі угруповання ОС США.

Показано, що Командування $A A M D C$ несе загальну відповідальність за планування операцій з ППО та ПРО сухопутної компоненти ОС та координацію і синхронізацію планування на рівні армійського корпусу та дивізії. Визначені основні заходи зі здійснення та результати планування $A A M D C$.

3. Проведено аналіз організації планування ППО/ПРО на рівні армійського корпусу СВ та бригади ППО СВ на ТВД. Визначений порядок та результати планування АК та бригадою ППО СВ. Показано, що через відсутність сил і засобів автоматизованого планування АК буде використовувати можливості бригади ППО для виконання більшості завдань 3 планування.

4. Складено узагальнену схему процесів планування ППО/ПРО сухопутної складової ОС на ланках управління від Командування ОС до батарей ППО СВ. Визначено, що планування здійснюється одночасно на всіх ланках управління паралельним методом із взаємним обміном результатами.

5. Показано, що ключовими документом планування ППО ОС є список об'єктів прикриття $D A L$ розроблення якого є динамічним та інтерактивним процесом в якому приймають участь всі органи управління $A D A$ у відповідності до етапу (фази) операції.

6. Визначені взаємопов'язані етапи розроблення $D A L$. Першим етапом є CVT-аналіз важливих об'єктів за критеріями "Критичність", “Чутливість” та “Відновлюваність”. Який передбачає кількісне оцінювання шляхом обробки експертних оцінок методами ранжування та шкальних оцінок, яким властива потенційна неузгодженість (слабка конкордація) оцінок експертів, через складність ранжування великої кількості важливих об'єктів.

7. Для повноти визначення особливостей планування протиповітряної оборони сухопутної складової ОС за стандартами НАТО необхідно провести аналіз методології вибору варіантів побудови системи прикриття важливих об’єктів (сил) від ударів 3 повітря та використання комплексної системи керування ризиками під час організації ППО.

Таблиця 2

Робоча таблиця CVT-аналізу типових об'єктів прикриття бтгр зі складу ОC

\begin{tabular}{|c|c|c|c|c|c|c|c|c|}
\hline $\begin{array}{c}\text { Список важливих } \\
\text { об'єктів (CAL) }\end{array}$ & $\begin{array}{c}\text { Ранг } \\
\text { “Критичність' } \\
\text { (Criticality) }\end{array}$ & $\begin{array}{c}\text { Ранг } \\
\text { "Уразливість" } \\
\text { (Vulnerability) }\end{array}$ & $\begin{array}{c}\text { Ранг } \\
\text { “Загроза" } \\
\text { (Threat) }\end{array}$ & $\begin{array}{c}\text { Загальна } \\
\text { сума } \\
\text { рангів }\end{array}$ & $\begin{array}{c}\text { Ранг } \\
C V T- \\
\text { аналізу }\end{array}$ & \multirow{3}{*}{ 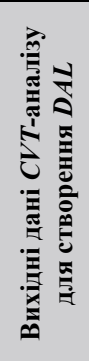 } & $\begin{array}{c}\text { Ранг } \\
\text { об'ск } \\
\text { тів } \\
\text { (сил) }\end{array}$ & $\begin{array}{l}\text { Список } \\
\text { об'єктів } \\
\text { (сил) }\end{array}$ \\
\hline $\begin{array}{c}\text { Передовий пункт боє- } \\
\text { постачання та дозаправ- } \\
\text { лення бртгр (FARP) }\end{array}$ & 4 & 1 & 2 & 7 & 1 & & 1 & FARP \\
\hline $\begin{array}{c}\text { Основний командний } \\
\text { пункт } \text { бртгр (BDE } \\
\text { TOC) }\end{array}$ & 1 & 7 & 6 & 14 & 3 & & 2 & $B S A$ \\
\hline
\end{tabular}


Закінчення табл. 2

\begin{tabular}{|c|c|c|c|c|c|c|c|c|}
\hline \begin{tabular}{|c|} 
Тиловий пункт управ- \\
ління бртгр (BSA) \\
\end{tabular} & 5 & 2 & 3 & 10 & 2 & \multirow{18}{*}{ 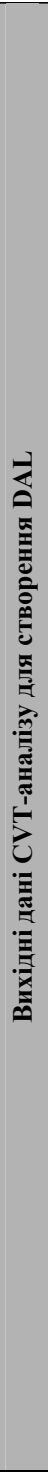 } & 3 & $\begin{array}{l}\text { BDE } \\
T O C \\
\end{array}$ \\
\hline $\begin{array}{c}\text { РЛС бртгр }(Q 36 / \\
\text { Sentinel })\end{array}$ & 2 & 12 & 3 & 15 & 4 & & 4 & $\begin{array}{c}36 / \\
\text { Sentinel } \\
\end{array}$ \\
\hline $\begin{array}{c}\text { Група тактичної авіа- } \\
\text { ційної підтримки } \\
\text { брта (AVN TAA) }\end{array}$ & 9 & 3 & 7 & 15 & 4 & & 5 & $\begin{array}{l}A V N \\
T A A\end{array}$ \\
\hline 1 батальйон $(B N 1 C P)$ & 12 & 17 & 10 & 39 & 11 & & 6 & UAS LRS \\
\hline 2 батальйон $(B N 2 C P)$ & 3 & 18 & 9 & 30 & 7 & & 7 & $\begin{array}{c}\text { Retrans } \\
1\end{array}$ \\
\hline 3 батальйон $(B N 3 C P)$ & 10 & 19 & 11 & 40 & 12 & & 8 & $C S S B$ \\
\hline \begin{tabular}{|l|} 
Підрозділи розвідки \\
бригади (CAV Scouts) \\
\end{tabular} & 11 & 20 & 5 & 36 & 8 & & 9 & $B N 2 C P$ \\
\hline \begin{tabular}{|c|} 
Ретрансляційний \\
пункт 1 (Retrans 1)
\end{tabular} & 6 & 15 & 4 & 25 & 6 & & 10 & $\begin{array}{c}\text { CAV } \\
\text { Scouts }\end{array}$ \\
\hline $\begin{array}{l}\text { Ретрансляційний } \\
\text { пункт 1(Retrans 2) }\end{array}$ & 13 & 16 & 12 & 41 & 13 & & 11 & ROLE 2 \\
\hline $\begin{array}{c}\text { Населений пункт } \\
\text { RAZISH }\end{array}$ & 17 & 4 & 16 & 37 & 10 & & 12 & RAZISH \\
\hline $\begin{array}{c}\text { Населений пункт } \\
\text { UJEN }\end{array}$ & 18 & 6 & 17 & 41 & 13 & & 13 & $B N 1 C P$ \\
\hline $\begin{array}{c}\text { Населений пункт } \\
B A R A S U \\
\end{array}$ & 19 & 9 & 18 & 46 & 15 & & 14 & $B N 3 C P$ \\
\hline $\begin{array}{c}\text { Населений пункт } \\
N A B R A N \\
\end{array}$ & 20 & 11 & 19 & 50 & 17 & & 15 & $\begin{array}{c}\text { Retrans } \\
2 \\
\end{array}$ \\
\hline $\begin{array}{c}\text { Позиція розташування } \\
\text { ротаційного підрозді- } \\
\text { лу бртгр (RUBA) }\end{array}$ & 16 & 13 & 20 & 49 & 16 & & 16 & UJEN \\
\hline $\begin{array}{c}\text { Ракетно- } \\
\text { артилерійський диві- } \\
\text { зіон бртгр (CSSB) } \\
\end{array}$ & 7 & 5 & 13 & 25 & 6 & & 17 & ROLE 3 \\
\hline $\begin{array}{c}\text { Інженерний підрозділ } \\
\text { бртгр } \\
(\text { ROLE 2) } \\
\end{array}$ & 14 & 10 & 14 & 38 & 9 & & 18 & $B A R A S U$ \\
\hline $\begin{array}{c}\text { Ремонтно- } \\
\text { відновлювальний під- } \\
\text { розділ бртгр (ROLE 3) }\end{array}$ & 15 & 14 & 15 & 44 & 14 & & 19 & $R U B A$ \\
\hline $\begin{array}{c}\text { Підрозділ БПЛА } \\
\text { бртгр } \\
(U A S L R S) \\
\end{array}$ & 8 & 8 & 8 & 24 & 5 & & 20 & $N A B R A N$ \\
\hline
\end{tabular}

Джерело: розроблено авторами.

\section{Список літератури}

1. Lucht M. Staff Handbook. Revised Edition / M. Lucht. - Leavenworth: Mission Training Complex, 2012. - 486 p.

2. Desk Reference. MDMP [Electronic resource] / Training Analysis Feedback Team. - Leavenworth: Mission Training Complex, 2015. - 398 p. - Available at: https://www.goodreads.com/book/show/22493408-us-army-staff-handbook.

3. Процес прийняття рішення на ведення бойових дій в сухопутних військах збройних сил країн НАТО / Л.І. Поліщук, О.К. Климович, С.М. Богуцький, О.Д. Пашетник // Озброєння та військова техніка. - 2018. - № 4. - С. 3-8.

4. Військовий посібник ГШ ЗС України про стандарти ведення бойових дій у ЗС держав НАТО (ВП 2.01.3; ВП 3.21.20; ВП 5.0А). - К.: ГШ ЗСУ, 2017. - 203 с.

5. Садовський М.С. Проблеми впровадження стандартів НАТО в функціонування Збройних Сил України / М.С. Садовський // Системи управління, навігації та зв'язку - 2016. - № 1(37). - С. 38-42.

6. Аналіз основних положень статуту бригади військ ППО СВ збройних сил США FM 3-01.7(3-01.11) / C.M. Піскунов, А.Ф. Волков, Ю.О. Галкін, М.М. Бречка // Збірник наукових праць Харківського національного університету Повітряних Сил. - 2019. - № 4(62) - С. 68-73. https://doi.org/10.30748/zhups.2019.62.09.

7. AJP-3.3.1. Allied Joint Doctrine for Counter-Air [Electronic resource] / NATO Standartization Agency, 2010. - 70 p. Available at: http://surl.li/mnjf.

8. JP 3-01. Countering Air and Missile Threats. - Washington: Joint Chiefs of Staff, 2012. - 199 p.

9. FM 44-100. U.S. Army Air and Missile Defense Operations. - Washington: Department of the Army, 2009. - 146 p.

10. ATP 3-01.8. Techniques for Combined Arms for Air Defense. - Washington: Department of the Army, 2016. - 68 p.

11. FM 44-100-2. Air Defense Artillery Reference Handbook. - Washington: Department of the Army, 2000. -139 p.

12. FM 3-01.7 Air Defense Artillery Brigade Operations. - Washington: Department of the Army, 2010. - 164 p.

13. JWP 3-63. Joint Air Defence. - Shrivenham: Joint Doctrine \& Concepts Centre, 2003. - 121 p.

14. FM 3-01.94. Army Air and Missile Defense Command Operations. - Washington: Department of the Army, 2000. - 124 p. 
15. FM 5-19. Composite Risk Management. - Washington: Department of the Army, 2006. - 108 p.

16. ATP 3-01.16. Air and Missile Defense Intelligence Preparation of the Battlefield. - Washington: Department of the Army, 2016. -90 p.

17. Бешелев С. Математико-статистические методы экспертных оценок / С. Бешелев, Ф. Гурвич. - М.: Статистика, 1980. $-264 \mathrm{c}$.

\section{Відомості про авторів:}

\section{Філіппенков Олексій Володимирович}

ад'юнкт

Харківського національного університету

Повітряних Сил ім. І. Кожедуба,

Харків, Україна

https://orcid.org/0000-0002-4027-6963

\section{Самоквіт Віталій Іванович}

старший викладач кафедри

Харківського національного університету

Повітряних Сил ім. І. Кожедуба,

Харків, Україна

https://orcid.org/0000-0002-4153-0281

\author{
Адамчук Максим Миколайович \\ кандидат військових наук доцент \\ заступник начальника кафедри \\ Національної академії Національної гвардії України, \\ Харків, Україна \\ https://orcid.org/0000-0001-9979-5509
}

\section{Дементіюк Георгій Михайлович}

начальник навчальної частини факультету

Харківського національного університету

Повітряних Сил ім. І. Кожедуба,

Харків, Україна

https://orcid.org/0000-0002-8770-8479

\section{Information about the authors:}

\author{
Oleksii Filippenkov \\ Doctoral Student \\ of Ivan Kozhedub Kharkiv National \\ Air Forces University, \\ Kharkiv, Ukraine \\ https://orcid.org/0000-0002-4027-6963
}

\author{
Vitaliy Samokvit \\ Senior Instructor of Department \\ of Ivan Kozhedub Kharkiv National \\ Air Force University, \\ Kharkiv, Ukraine \\ https://orcid.org/0000-0002-4153-0281
}

\author{
Maksim Adamchuk \\ Candidate of Military Sciences Associate Professor \\ Deputy Head of Department \\ of National Academy of National Guard of Ukraine, \\ Kharkiv, Ukraine \\ https://orcid.org/0000-0001-9979-5509
}

\author{
Heorhii Dementiiuk \\ Chief of Educational Cell \\ of Ivan Kozhedub Kharkiv National \\ Air Force University, \\ Kharkiv, Ukraine \\ https://orcid.org/0000-0002-8770-8479
}

\title{
АНАЛИЗ ОСОБЕННОСТЕЙ ОПЕРАТИВНОГО ПЛАНИРОВАНИЯ ПРОТИВОВОЗДУШНОЙ ОБОРОНЫ СУХОПУТНЫХ ВОЙСК ОБЪЕДИНЁННЫХ СИЛ ПО СТАНДАРТАМ НАТО
}

\author{
А.В. Филиппенков, В.И. Самоквит, М.М. Адамчук, Г.М. Дементиюк
}

Проведен анализ особенностей организации и проведения оперативного планирования противовоздушной обороны (ПВО) сухопутных войск объединённых сил по стандартам НАТО. На примере объединённых сил (ОС) США приведено распределение обязанностей по планированию ПВО между командованием ОС и его функииональными составляющими. Определены основные составляюшие ППО СВ в составе группировки ОС США. Показано, что Командование ППО $C B$ несет общую ответственность за планирование операций по ПВО и противоракетной обороне (ПРО) сухопутной компоненты $О С$, координацию и синхронизачию планирования на уровне армейского корпуса и дивизии. Проведен анализ организачии планирования ПВО / ПРО на уровне армейского корпуса СВ и бригады ПВО СВ на театре военных действий (ТВД). Показано, что возможности бригады ПВО на ТВД позволяют организовать планирование на уровнях командования ПВО СВ и армейского корпуса. Составлен обобщенную схему процессов планирования ПВО / ПРО сухопутной составляющей ОС на звеньях управления от Командования ОС к батареям ПВО СВ. Определено, что ключевыми документами по планированию ПВО является список важных объектов и список прикрытия разработка которых является динамическим и интерактивным процессом в соответствии с этапом (фазой) операции.

Ключевые слова: противовоздушная оборона, оперативное планирование, операция Объединенных сил, список важных объектов, список объектов прикрытия, СVT-анализ. 


\section{THE ANALYSIS OF PECULIARITIES OF OPERATIONAL PLANNING OF AIR DEFENSE OF THE JOINT FORCES BY NATO STANDARDS}

\section{O. Filippenkov, V. Samokvit, M. Adamchuk, H. Dementiiuk}

The analysis of the features of organizing and conducting operational planning of air defense artillery (ADA) of the ground forces of the joint forces according to NATO standards. Using the example of the Joint Forces (JFOR) of the United States, the distribution of responsibilities for planning air defense between the JFOR Command and Commands of its functional components is given. The main components of the ADA as part of the JFOR have been determined. It is shown that the Army Air and Missile Defense Command (AAMDC) has overall responsibility for planning air defense and missile defense (ADM) operations of the ground component of the JFOR, coordinating and synchronizing planning at the army corps and division levels. The analysis of the organization of ADM planning at the level of the army corps of the ground forces and the ADA brigade on the theater. It is shown that the capabilities of the air defense brigade in the theater of operations make it possible to organize planning at the levels of the air defense command of the ground forces and the army corps. A generalized diagram of the planning processes for the ADM of the army forces of the JFOR was drawn up at the command links from the JFOR Command to the air defense batteries of the air defense. It was determined that the key documents for air defense planning are the Critical Assets List (CAL) and a Defended Assets List (DAL). The development of mentioned lists is a dynamic and interactive process which conducted in accordance with the stage (phase) of the joint operation. The interrelated stages of development of the list of cover objects are determined and the methods that are used for this are characterized. Interconnection stages of DAL creating were defined. The main stage based on CVT-analysis of the critical objects in the Area of Operation according to the following criteria: "Criticality", "Sensitivity" and "Recuperability". The analysis provided in terms of expert assessment methodology with ranking and scale of the assessments. It was reported potential ineffectiveness (weak concordance) of the experts assessments due to complicity of scaling in case of large number of critical objects.

Keywords: air defense, operational planning, Joint Force operation, critical assets list, defended assets list, CVT-analysis. 